\title{
Large-scale study of antibody titer decay following BNT162b2 mRNA vaccine or SARS-CoV-2 infection
}

Ariel Israel ${ }^{1}$ MD, PhD (e-mail: dr.ariel.israel@gmail.com, 0000-0003-4389-8896)

Yotam Shenhar MD (e-mail: yshenhar@leumit.co.il)

Ilan Green ${ }^{1,2}$ MD (e-mail: igreen@leumit.co.il)

Eugene Merzon ${ }^{1,2}$ MD (e-mail: emarzon@leumit.co.il, 0000-0001-5469-0236)

Avivit Golan-Cohen ${ }^{1,2}$ MD (e-mail: agolanchoen@leumit.co.il)

Alejandro A Schäffer ${ }^{3}$, PhD (e-mail: alejandro.schaffer@nih.gov, 0000-0002-2147-8033)

Eytan Ruppin ${ }^{3}$, MD, PhD (e-mail: eytan.ruppin@nih.gov, 0000-0002-7862-3940)

Shlomo Vinker ${ }^{1,2}$ MD, MHA (e-mail: svinker@leumit.co.il, 0000-0001-9804-7103)

Eli Magen ${ }^{1,4}$ MD (e-mail: allergologycom@gmail.com, 0000-0002-7713-423X)

\section{Authors Affiliations:}

${ }^{1}$ Leumit Research Institute \& Department of Family Medicine, Leumit Health Services, Israel

${ }^{2}$ Department of Family Medicine, Sackler Faculty of Medicine, Tel-Aviv University, Tel-Aviv, Israel

${ }^{3}$ Cancer Data Science Laboratory, National Cancer Institute, Bethesda, MD USA

${ }^{4}$ Medicine C Department, Clinical Immunology and Allergy Division, Barzilai University Medical Center, Ben Gurion University of the Negev, Israel

\section{Correspondence to:}

Ariel Israel, MD, PhD

Leumit Research Institute

Leumit Health Services

23 Sprinzak St., Tel-Aviv, Israel

Telephone: 03-6970485

Email: dr.ariel.israel@gmail.com 
Impact statement: Large scale study display the kinetics of SARS-CoV-2 IgG antibodies present in individuals vaccinated with two doses of mRNA vaccine vs. unvaccinated patients who had recovered from the disease: initial levels of antibody are much higher in vaccinated patients, but decrease faster.

Conflict of Interest disclosure statement: All authors have no conflicts to disclose

Keywords: antibody titer; BNT162b2 mRNA vaccine; SARS-CoV-2 infection

\section{Abbreviations}

COVID-19 - Coronavirus disease of 2019

SARS-CoV-2 - Severe acute respiratory syndrome coronavirus 2

mRNA - Messenger RNA

LHS - Leumit Health Services

HMO - Health maintenance organization

SES - Socio-economic status

BMI - Body mass Index

IQR - Interquartile range

RT-PCR - Reverse transcription polymerase chain reaction

IgG - Immunoglobulin G

BMPCs - Bone marrow plasma cells

ACE2 - Angiotensin-converting enzyme 2 
medRxiv preprint doi: https://doi.org/10.1101/2021.08.19.21262111; this version posted August 22, 2021. The copyright holder for this preprint (which was not certified by peer review) is the author/funder, who has granted medRxiv a license to display the preprint in perpetuity.

It is made available under a CC-BY-NC-ND 4.0 International license .

\section{Abstract}

Background: Immune protection following either vaccination or infection with SARS-CoV-2 decreases over time.

Objective: To determine the kinetics of SARS-CoV-2 IgG antibodies following administration of two doses of BNT162b2 vaccine, or SARS-CoV-2 infection in unvaccinated individuals.

Methods: Antibody titers were measured between January 31, 2021, and July 31, 2021 in two mutually exclusive groups: i) vaccinated individuals who received two doses of BNT162b2 vaccine and had no history of previous infection with COVID-19 and ii) SARS-CoV2 convalescents who had not received the vaccine.

Results: A total of 2,653 individuals fully vaccinated by two doses of vaccine during the study period and 4,361 convalescent patients were included. Higher SARS-CoV-2 IgG antibody titers were observed in vaccinated individuals (median $1581 \mathrm{AU} / \mathrm{mL}$ IQR [533.85644.6]) after the second vaccination, than in convalescent individuals (median 355.3 AU/mL IQR [141.2-998.7]; $p<0.001)$. In vaccinated subjects, antibody titers decreased by up to $40 \%$ each subsequent month while in convalescents they decreased by less than $5 \%$ per month. Six months after BNT162b2 vaccination 16.1\% subjects had antibody levels below the seropositivity threshold of $<50 \mathrm{AU} / \mathrm{mL}$, while only $10.8 \%$ of convalescent patients were below $<50 \mathrm{AU} / \mathrm{mL}$ threshold after 9 months from SARS-CoV-2 infection.

Conclusions: This study demonstrates individuals who received the Pfizer-BioNTech mRNA vaccine have different kinetics of antibody levels compared to patients who had been infected with the SARS-CoV-2 virus, with higher initial levels but a much faster exponential decrease in the first group.

Funding: This research was internally funded by Leumit Health Services (LHS) and was supported in part by the Intramural Research Program, National Institutes of Health, National Cancer Institute, Center for Cancer Research.

The content of this publication does not necessarily reflect the views or policies of the Department of Health and Human Services, nor does mention of trade names, commercial products, or organizations imply endorsement by the U.S. Government. 
medRxiv preprint doi: https://doi.org/10.1101/2021.08.19.21262111; this version posted August 22, 2021. The copyright holder for this preprint (which was not certified by peer review) is the author/funder, who has granted medRxiv a license to display the preprint in perpetuity.

It is made available under a CC-BY-NC-ND 4.0 International license .

\section{Introduction}

Immunity to severe acute respiratory syndrome coronavirus 2 (SARS-CoV-2) has been induced either through SARS-CoV-2 infection or vaccination and induces protection against reinfection or decreases the risk of clinically significant consequences(Khoury et al., 2021). While convalesced seropositive individuals have approximately $90 \%$ protection from SARSCoV-2 reinfection, the effectiveness of vaccination has been reported as 50 - 95\%(Kim et al., 2021; Lumley, 2021). Nevertheless, both the memory B cell humoral response and spikespecific $\mathrm{CD}_{4}^{+}$cellular immune responses to SARS-CoV-2 are predictably diminishing over time(Gaebler et al., 2021; Wheatley et al., 2021). Therefore, there is a great concern regarding the weakened SARS-CoV-2 immune protection both in the vaccinated and convalescent populations(Wang et al., 2021).

Israel was among the first countries to initiate a large-scale vaccination campaign, on December 20th 2020, and quickly immunized a high proportion of the adult population, achieving early control over the spread of the virus(Raz et al., 2021). More than five million Israelis (out of 9.3 million) have been fully vaccinated with two doses of the Pfizer-BioNTech vaccine as of May 26, 2021(“Covid-19 dashboard," n.d.). However, in recent weeks, there has been a resurgence of SARS-CoV-2 cases in Israel. It is important to understand to what extent this resurgence is due to the high infectiousness of the delta variant(Chakraborty et al., 2021), lower protection of the vaccine against the delta or other variants as compared to the original strain(Faulkner et al., 2021; Martínez-Flores et al., 2021), or decreasing levels of anti-SARS-CoV-2 antibodies against all strains in vaccinated individuals(Israel et al., 2021). 
medRxiv preprint doi: https://doi.org/10.1101/2021.08.19.21262111; this version posted August 22, 2021. The copyright holder for this preprint (which was not certified by peer review) is the author/funder, who has granted medRxiv a license to display the preprint in perpetuity.

It is made available under a CC-BY-NC-ND 4.0 International license .

Here, tracing one of these key factors, we describe the results of a large-scale study measuring the decrease rate of antibodies following administration of two doses of BNT162b2 vaccine, or SARS-CoV-2 infection in unvaccinated individuals in Israel.

\section{Methods}

We conducted a population-based study among adult members of Leumit Health Services (LHS), a large nation-wide health maintenance organization (HMO) in Israel, which provides services to over 700,000 members. LHS has a comprehensive computerized database, continuously updated regarding subjects' demographics, medical diagnoses, medical encounters, hospitalizations and laboratory tests. The Socio-economic status (SES) was defined according to a person's home address. The Israeli Central Bureau of Statistics classifies all cities and settlements into 20 levels of SES. Ethnicity was also defined according to the home address of the HMO member, and categorized into three groups: General population, Ultra-Orthodox Jews and Arabs; the latter two groups are of interest because a large-scale epidemiology study showed that they had significantly higher rates of infection than the rest of the Israeli population(Muhsen et al., 2021).

All LHS members have similar health insurance coverage and similar access to healthcare services. During each physician visit, a diagnosis is entered or updated according to the International Classification of Diseases $9^{\text {th }}$ revision (ICD-9). The validity of chronic diagnoses in the registry has been previously examined and confirmed as high(Hamood et al., 2016; Rennert and Peterburg, 2001).

We extracted serology results and associated demographic and clinical data for members aged 18 or older, who underwent a SARS-CoV-2 serology test between January 31, 2021, and July 31, 2021, following either two vaccine injections, or documented COVID-19 
medRxiv preprint doi: https://doi.org/10.1101/2021.08.19.21262111; this version posted August 22, 2021. The copyright holder for this preprint (which was not certified by peer review) is the author/funder, who has granted medRxiv a license to display the preprint in perpetuity.

It is made available under a CC-BY-NC-ND 4.0 International license .

infection. Patients who had had received a vaccine injection and had a documented COVID19 infection were excluded from the study.

Baseline data from individuals included in the cohort were extracted as of May 15, 2021, including age. All the clinical diagnoses were based on ICD-9 codes. During each physician visit, a diagnosis is entered or updated according to the International Classification of Diseases $9^{\text {th }}$ revision (ICD-9). We tested for the main medical conditions expected to affect the severity of COVID-19 infection or the serology count in adult population: diabetes mellitus, hypertension, asthma, chronic obstructive pulmonary disease, ischemic heart disease, presence of malignancy, and chronic kidney disease.

\section{SARS-CoV-2 testing by real-time RT-PCR}

Nasopharyngeal swabs were taken and examined for SARS-CoV-2 by real-time RT-PCR performed with internal positive and negative controls, according to World Health Organization guidelines. The Allplex 2019-nCoV assay (Seegene, Seoul, Korea) was used until March 10, 2020, after which time the COBAS SARS-Cov-2 6800/8800 assay (Roche Pharmaceuticals, Basel, Switzerland) was employed.

\section{SARS-CoV-2 IgG testing}

Serum samples were run on the SARS-CoV-2 IgG lab-based serology blood test on the Abbot

Alinity $^{\text {Tm }}$ i system following the manufacturer's instructions. In this antibody CMIA test, the SARS-CoV-2 antigen-coated paramagnetic microparticles bind to the IgG antibodies that attach to the SARS-CoV-2 spike protein (SP) in patients' serum and plasma sample and it requires a minimum of $100 \mu \mathrm{l}$ of serum or plasma. The resulting chemiluminescence in relative light units following the addition of anti-human IgG-labeled in comparison with the 
medRxiv preprint doi: https://doi.org/10.1101/2021.08.19.21262111; this version posted August 22, 2021. The copyright holder for this preprint (which was not certified by peer review) is the author/funder, who has granted medRxiv a license to display the preprint in perpetuity.

It is made available under a CC-BY-NC-ND 4.0 International license .

IgG II calibrator/standard indicates the strength of the response, which reflects the quantity of IgG to SP. IgG antibody levels measured by this test below $50 \mathrm{AU} / \mathrm{mL}$ are considered nonprotective. In internal testing, I Abbot Alinitl ${ }^{\text {tm }}$ i system showed reliable results with $99.6 \%$ specificity and $100 \%$ sensitivity for COVID-19 patients tested 14 days after symptoms began (“Abbott Receives FDA Emergency Use Authorization for COVID-19 Antibody Blood Test on Alinity ${ }^{\mathrm{TM}}$ i System - May 11, 2020," n.d.). The Abbot assay has been validated externally(Bryan et al., 2020; Perkmann et al., 2020; Zabelin et al., n.d.) with sensitivity $96.77 \%$, specificity $99 \%$ and the caveat that these numbers depend on the boundaries of the middle range. Qualitative results and index values reported by the system were used in analyses.

The study protocol was approved by Shamir Medical Center Institutional Review Board (129-2-LEU).

\section{Statistical Analyses}

Standard descriptive statistics were used to present the demographic characteristics of patients included in this study and their measured antibody levels. Differences in demographic and clinical characteristics between groups were analyzed using MannWhitney $U$ test and Fisher's exact test for continuous and categorical variables, respectively. Categorical data are shown in counts and percentages. Data on continuous variables are presented as mean and standard deviation, non-normal variables are displayed as median and interquartile range. Linear regression models were fit to quantify the association between time since the second vaccination in vaccinated individuals or time since the first positive PCR in convalescents, and the logarithm of antibody levels. When converted to the logarithmic scale, zero values were replaced by one. For convenience, regression 
medRxiv preprint doi: https://doi.org/10.1101/2021.08.19.21262111; this version posted August 22, 2021. The copyright holder for this preprint (which was not certified by peer review) is the author/funder, who has granted medRxiv a license to display the preprint in perpetuity.

It is made available under a CC-BY-NC-ND 4.0 International license .

coefficients are displayed in figures and tables in the natural scale (after exponentiation).

Multivariable regression models were also fit to measure the effect associated for each

different age categories (18-59 years, more than 60 ), sex, ethnic group, SES, comorbidity

factor, and disease severity (presence of symptoms and admission to hospital during disease

in convalescent patients).

\section{Software}

All statistical analyses were conducted using R software version 4.0.3 (R Foundation).

\section{Role of the funding source}

The National Institute of Health had no role in study design, data collection, data analysis, data interpretation, or writing of the report. AI, EM and IG had full access to all the data in the study and had final responsibility for the decision to submit for publication.

\section{Results}

During the study period, serology assays to quantify SARS-CoV-2 levels were performed for 2,653 vaccinated individuals who never had a positive SARS-Cov2 PCR test or serology test in the past, and 4,361 patients recovering from SARS-CoV-2 and who had not been vaccinated, at various times after the vaccination or infection.

Table 1 describes the demographic characteristics and serology results for tested individuals in the vaccinated population and the COVID-19 convalescent individuals, according to the time that has elapsed until the serology test. The convalescent population was younger ( $41.99 \pm 16.09$ years) than the vaccinated population ( $56.45 \pm 15.87$ years) and was characterized by lower socioeconomic status (SES) and a higher proportion of Ultra-orthodox and Arab subjects (Table 1). The mean period since the SARS-CoV-2 IgG lab- 
medRxiv preprint doi: https://doi.org/10.1101/2021.08.19.21262111; this version posted August 22, 2021. The copyright holder for this preprint (which was not certified by peer review) is the author/funder, who has granted medRxiv a license to display the preprint in perpetuity.

It is made available under a CC-BY-NC-ND 4.0 International license .

based serology test after the 2 nd dose of vaccination was $101 \pm 66$ days, while since the first positive PCR in convalescents was $151 \pm 82$ days.

Table $2 \mathrm{a}$ and $2 \mathrm{~b}$ display SARS-CoV-2 IgG antibody titers measured in vaccinated and convalescent individuals, in intervals spaced 30 days apart, since second vaccination (for the vaccinated) or first positive PCR (for convalescents). Lab-based serology is available for up to six months following vaccination for the vaccinated and up to nine months for convalescent patients. The age distribution of the patients for which serology was tested varies slightly throughout the follow-up, so it is indicated in the tables.

We observe considerably higher titers in the first month following the second vaccination (median 9913, IQR [3650-18,733]) than in convalescent patients after SARS-CoV-2 infection (median 490, IQR [109-1869] in the first month). In the convalescent subjects, the maximal mean antibody response was observed at 3 months after the documented COVID-19 infection, then the mean SARS-CoV-2 IgG antibody titer decreases slightly each subsequent month from the highest mean antibody response. The vaccination with the BNT162b2 vaccine-elicited much higher antibody titers at 3 months compared to the titers collected in serum from convalescent patients. However, in these vaccinated individuals who never had a positive PCR test, the mean SARS-CoV-2 IgG antibody titer decreased by up to $40 \%$ each subsequent month from the highest mean antibody response. Consequently, we observed in BNT162b2 vaccinated subjects a worrisome decline in the proportion of people whose antibody levels are below the seropositivity threshold of $<50 \mathrm{AU} / \mathrm{mL}$ (considered nonprotective) from $5.8 \%$ in the first 3 months, to $16.1 \%$ after 6 months (Figure 1a) while only $10.8 \%$ of convalescent patients are below the $50 \mathrm{AU} / \mathrm{mL}$ threshold after 9 months (Figure 1b). 
medRxiv preprint doi: https://doi.org/10.1101/2021.08.19.21262111; this version posted August 22, 2021. The copyright holder for this preprint (which was not certified by peer review) is the author/funder, who has granted medRxiv a license to display the preprint in perpetuity.

It is made available under a CC-BY-NC-ND 4.0 International license .

We performed linear regression models to quantify the association between elapsed time and antibody levels, in both vaccinated and convalescent individuals. In both populations, there was a strong association $(p<0.001)$ between elapsing time and antibody titers. Figure 1a. and 1b. display scatter plots with antibody titers plotted against elapsed time. In the vaccinated population, we observe higher initial antibody titers (intercept of 6366 at time zero), but the titers quickly drop, decreasing by $40 \%$ each passing month. Conversely, in the convalescent population, initial titers are lower (intercept of 357 at time zero), but the titers decrease much more slowly, by $4 \%$ every month.

To assess possible effects of age, sex, ethnic group, SES in addition to time since the second vaccination or since the first positive PCR in convalescents on antibody levels, we performed multivariable regression models on the vaccinated and convalescent cohorts (Table 3 ). In both populations, there was a strong association $(p<0.001)$ between elapsed time and antibody titers: each month was associated with a mean decay factor of $0.623[95 \% \mathrm{Cl}$ 0.599-0.649] in vaccinated patient, while for convalescent patients the decrease was only by a factor of 0.960 [95\% $\mathrm{Cl} 0.939-0.982]$. Among the vaccinated, antibody titers decreased with older age (factor 0.790 [95\% $\mathrm{Cl} 0.644-0.969]$ for age $\geq 60$ ), chronic renal disease (factor 0.200 [95\% Cl 0.143-0.281]), underweight (factor 0.359 [95\% Cl 0.144-0.893] for $\mathrm{BMI}<18.5$ ), solid malignancy (factor 0.642 [95\% Cl 0.494-0.834]), COPD (factor 0.643 [95\% Cl 0.4790.863]), patients with diabetes mellitus (factor 0.720 [95\% Cl 0.579-0.894]), and hypertension (factor 0.786 [95\% Cl 0.639-0.966]); they were increased in females (factor 1.243 [95\% Cl 1.035-1.492]) and in Arab and Jewish Ultra-orthodox subjects. In the convalescent, antibody titers were higher for symptomatic patients (factor 1.811 [95\% Cl 1.531-2.142]), those who had been admitted to the hospital (factor 3.323 [95\% Cl 2.2174.980]) and those with risk factors for severe disease: older age (factor 1.546 [95\% $\mathrm{Cl} 1.269$ - 
medRxiv preprint doi: https://doi.org/10.1101/2021.08.19.21262111; this version posted August 22, 2021. The copyright holder for this preprint (which was not certified by peer review) is the author/funder, who has granted medRxiv a license to display the preprint in perpetuity.

It is made available under a CC-BY-NC-ND 4.0 International license .

1.884] for age $\geq 60$ ), obesity (factor 1.839 [95\% $\mathrm{Cl} 1.166-2.899]$ for $\mathrm{BMI}>35$ ), diabetes mellitus (factor 1.354 [95\% Cl 1.093-1.678]), hypertension (factor 1.254 [95\% Cl 1.036-1.518]), and chronic renal disease (factor 1.965 [95\% $\mathrm{Cl} 1.134-3.407])$.

\section{Discussion}

In this large population of individuals tested for SARS-CoV-2 antibody titer following either vaccination or documented COVID-19 infection, we correlated antibody titers to the time that has elapsed since exposure to vaccine or virus. Among never infected individuals who received the Pfizer-BioNTech mRNA vaccine, we found higher initial antibody levels followed by a faster decrease rate compared to patients who had been infected with the SARS-CoV-2 virus. As a corollary of that, the proportion of vaccinated individuals whose antibody levels drop below the threshold thought to be protective is increasing substantially by the fifth month, while it is uncommon in convalescent individuals.

Real world data about the time evolution of SARS-CoV-2 antibodies after vaccinations against SARS-CoV-2 and after the COVID-19 infection are limited. Several studies reported on the humoral response following the BNT162b2 mRNA COVID-19 vaccination and found that SARS-CoV-2 antibody titers 4 to 6 months after infection decline more slowly than in the initial months after the infection (Ebinger et al., 2021; Padoan et al., 2021; Tré-Hardy et al., 2021). At least two recent studies reported that antibodies could be detected up to 11 months after infection and provided evidence that that these antibodies originated in memory B cells, not plasmablasts(Tong et al., 2021; Turner et al., 2021a). Generation of SARS-CoV-2 memory B cells(De Gasparo et al., 2021; Schoof et al., 2020; Xu et al., 2021) is 
medRxiv preprint doi: https://doi.org/10.1101/2021.08.19.21262111; this version posted August 22, 2021. The copyright holder for this preprint (which was not certified by peer review) is the author/funder, who has granted medRxiv a license to display the preprint in perpetuity.

It is made available under a CC-BY-NC-ND 4.0 International license .

likely necessary for long-term protection since that is the mechanism by which most antiviral vaccines work(Iwasaki, 2016).

The strength of our study is that it provides such information in a relatively large cohort of both vaccinated individuals and patients recovering from SARS-CoV-2. It shows that the declining slope of antibodies in vaccinated individuals is much steeper than in convalescent individuals. Other studies reported on the persistence of the humoral response in vaccinated subjects, but the follow-up of the participants was usually below 3 months(Salvagno et al., 2021; Tré-Hardy et al., 2021; Turner et al., 2021b). This study has several limitations. First, given the observational design, there is potential for unmeasured confounding factors. In particular, participants in this study were individuals who elected to have a serology test for SARS-CoV-2 during the study period, many of them as part of a survey. Individuals may have variable reasons for accepting or refusing the offered serology test, which may have affected the results of this survey. Additionally, even though we adjusted our results for known factors that could affect antibody production and decay, additional factors may have affected the results.

The BNT162b2 mRNA COVID-19 vaccine has been shown to stimulate production of antibodies to several SARS-CoV-2 proteins, not just the spike protein, suggesting that the vaccine provides short-term protection against variant strains(Amanat et al., 2021; Turner et al., 2021b). Combining these results with ours suggests that the recent surge in breakthrough infections in fully vaccinated individuals is due at least in part to declining levels of antibodies and not solely due to the variant strains of SARS-CoV-2. In a recent single-center, prospective, cross-sectional cohort study, children's immunity was found to decline 4 months after the COVID-19 infection(Breuer et al., 2021). Lyer et al. reported that 
medRxiv preprint doi: https://doi.org/10.1101/2021.08.19.21262111; this version posted August 22, 2021. The copyright holder for this preprint (which was not certified by peer review) is the author/funder, who has granted medRxiv a license to display the preprint in perpetuity.

It is made available under a CC-BY-NC-ND 4.0 International license .

anti-S-protein antibodies reserved neutralizing abilities and persevered for up to 75 days after SARS-CoV-2 infection in $>95 \%$ of patients(lyer et al., 2020). Gudbjartsson et al. showed that SARS-CoV-2 IgG levels do not wane up to 4 months after infection(Gudbjartsson et al., 2020).

Shortly after vaccination, the BNT162b2 mRNA vaccine was shown to protect against COVID19 through multiple beneficial mechanisms, by eliciting robust $\mathrm{CD} 4^{+}$and $\mathrm{CD} 8^{+} \mathrm{T}$ cell responses and strong antibody responses to the receptor-binding domain (RBD) of the SARS-CoV-2 spike protein, with RBD-binding IgG concentrations clearly above those seen in serum from a cohort of individuals who had recovered from COVID-19(Sahin et al., 2020). These effective humoral and cellular immune responses were observed a week after the booster dose, with the negligible immune response between the first and second doses(Sahin et al., 2020).

Bone marrow plasma cells (BMPCs) are an essential source of medium-term protective antibodies both after vaccination and infection(Halliley et al., 2015; Nutt et al., 2015), but longer-term protection likely requires memory B cells(Iwasaki, 2016; Turner et al., 2021a). Individuals who have recovered from COVID-19 have a significantly lower risk of SARS-CoV-2 reinfection(Hall et al., 2021). A recent 12-month longitudinal study was published with 1,782 plasma samples from 869 convalescent plasma donors in Wuhan, China. This study has shown that among COVID-19 plasma donors the positive rate of IgG antibody against the SARS-CoV-2 receptor binding domain (RBD) in the spike protein exceeded 70\% for 12 months post-diagnosis(C. Li et al., 2021). In our study, we show that following vaccination, the levels of anti-SARS-CoV-2 antibodies decrease rapidly, indicating that BMPCs may not be created adequately and therefore anti-SARS-CoV-2 humoral immunity might be 
medRxiv preprint doi: https://doi.org/10.1101/2021.08.19.21262111; this version posted August 22, 2021. The copyright holder for this preprint (which was not certified by peer review) is the author/funder, who has granted medRxiv a license to display the preprint in perpetuity.

It is made available under a CC-BY-NC-ND 4.0 International license .

transient(Ibarrondo et al., 2020; Seow et al., 2020). After infection, SARS-CoV-2 proteins and nucleic acids could remain in the gut for at least two months, boosting the continued antibody evolution in germinal centers, preferring epitopes overlapping with the ACE2binding site on the RBD(Gaebler et al., 2021).

It is widely accepted that neutralizing serum antibodies provide a strong protective role from SARS-CoV-2 in both nonhuman primates animal models and in humans(D. Li et al., 2021; McMahan et al., 2020). The assay used in our study does not specially measure neutralizing antibody, nevertheless, a high correlation was observed between a surrogate virus neutralization assay and other assays such as Roche Elecsys anti-S pan-Ig assay(L'Huillier et al., 2021).

Remarkably, after BNT162b2 mRNA vaccination, we observed higher SARS-CoV-2 antibody titers in the convalescent individuals aged $\geq 60$ years, while in the vaccinated population higher SARS-CoV-2 antibody titers were seen in younger patients. Clinically, in a recent study performed in our health organization among individuals who had received two doses of the BNT162b2 vaccine, we observed a significantly higher rate of SARS-CoV-2 infection among patients who have received their second vaccine dose for more than 146 days: the increase was significant for all age groups, with the strongest increase observed for patients aged 60 or more(Israel et al., 2021). The decrease of SARS-CoV-2 IgG antibodies observed in the present study provides one explanation for the increased infection rate found after 146 days in this age group and may warrant a third vaccine dose before the fifth month in populations at risk. Our observations call for replication in other populations to further correlate of protection against SARS-CoV-2 reinfection and/or COVID-19 disease and the duration of antibody-mediated protection. 
medRxiv preprint doi: https://doi.org/10.1101/2021.08.19.21262111; this version posted August 22, 2021. The copyright holder for this preprint

(which was not certified by peer review) is the author/funder, who has granted medRxiv a license to display the preprint in perpetuity.

It is made available under a CC-BY-NC-ND 4.0 International license .

\section{Contributors}

All authors provided final approval to publish The corresponding author attests that all listed authors meet authorship criteria and that no others meeting the criteria have been omitted.

Al is the guarantor.

\section{Competing interests}

All authors have completed the ICMJE uniform disclosure form at www.icmje.org/coi_disclosure.pdf. The authors declare no competing interests. Al, YS, EM, IG, AGC, SV and EM are employees of Leumit Health Services. All authors declare that they have no other relationships or activities that could appear to have influenced the submitted work.

\section{Data Availability Statement}

This study is based on real-world patient data, including demographics, comorbidity factors, that cannot be communicated due to patient privacy concerns. 
medRxiv preprint doi: https://doi.org/10.1101/2021.08.19.21262111; this version posted August 22, 2021. The copyright holder for this preprint (which was not certified by peer review) is the author/funder, who has granted medRxiv a license to display the preprint in perpetuity.

It is made available under a CC-BY-NC-ND 4.0 International license .

\section{References}

Abbott Receives FDA Emergency Use Authorization for COVID-19 Antibody Blood Test on Alinity $^{\mathrm{TM}}$ i System - May 11, 2020. n.d. https://abbott.mediaroom.com/2020-05-11Abbott-Receives-FDA-Emergency-Use-Authorization-for-COVID-19-Antibody-BloodTest-on-Alinity-TM-i-System

Amanat F, Thapa M, Lei T, Ahmed SMS, Adelsberg DC, Carreño JM, Strohmeier S, Schmitz AJ, Zafar S, Zhou JQ, Rijnink W, Alshammary H, Borcherding N, Reiche AG, Srivastava K, Sordillo EM, van Bakel H, Personalized Virology Initiative, Turner JS, Bajic G, Simon V, Ellebedy AH, Krammer F. 2021. SARS-CoV-2 mRNA vaccination induces functionally diverse antibodies to NTD, RBD, and S2. Cell 184:3936-3948.e10. doi:10.1016/j.cell.2021.06.005

Breuer A, Raphael A, Stern H, Odeh M, Fiszlinski J, Algur N, Magen S, Megged O, Schlesinger Y, Barak-Corren Y, Heiman E. 2021. SARS-CoV-2 antibodies started to decline just four months after COVID-19 infection in a paediatric population. Acta Paediatr 00:1-9. doi:10.1111/APA.16031

Bryan A, Pepper G, Wener MH, Fink SL, Morishima C, Chaudhary A, Jerome KR, Mathias PC, Greninger AL. 2020. Performance Characteristics of the Abbott Architect SARS-CoV-2 IgG Assay and Seroprevalence in Boise, Idaho. J Clin Microbiol 58. doi:10.1128/JCM.00941-20

Chakraborty C, Bhattacharya M, Sharma AR. 2021. Present variants of concern and variants of interest of severe acute respiratory syndrome coronavirus 2 : Their significant mutations in S-glycoprotein, infectivity, re-infectivity, immune escape and vaccines activity. Rev Med Virol e2270. doi:10.1002/RMV.2270

Covid-19 dashboard. n.d. https://datadashboard.health.gov.il/COVID-19/

De Gasparo R, Pedotti M, Simonelli L, Nickl P, Muecksch F, Cassaniti I, Percivalle E, Lorenzi JCC, Mazzola F, Magrì D, Michalcikova T, Haviernik J, Honig V, Mrazkova B, Polakova N, Fortova A, Tureckova J, latsiuk V, Di Girolamo S, Palus M, Zudova D, Bednar P, Bukova I, Bianchini F, Mehn D, Nencka R, Strakova P, Pavlis O, Rozman J, Gioria S, Sammartino JC, Giardina F, Gaiarsa S, Pan-Hammarström Q, Barnes CO, Bjorkman PJ, Calzolai L, Piralla A, Baldanti F, Nussenzweig MC, Bieniasz PD, Hatziioannou T, Prochazka J, Sedlacek R, Robbiani DF, Ruzek D, Varani L. 2021. Bispecific IgG neutralizes SARS-CoV-2 variants and prevents escape in mice. Nat 20215937859 593:424-428. doi:10.1038/s41586021-03461-y

Ebinger JE, Fert-Bober J, Printsev I, Wu M, Sun N, Prostko JC, Frias EC, Stewart JL, Van Eyk JE, Braun JG, Cheng S, Sobhani K. 2021. Antibody responses to the BNT162b2 mRNA vaccine in individuals previously infected with SARS-CoV-2. Nat Med 2021276 27:981984. doi:10.1038/s41591-021-01325-6

Faulkner N, Ng KW, Wu MY, Harvey R, Margaritis M, Paraskevopoulou S, Houlihan C, Hussain S, Greco M, Bolland W, Warchal S, Heaney J, Rickman H, Spyer M, Frampton D, Byott M, de Oliveira T, Sigal A, Kjaer S, Swanton C, Gandhi S, Beale R, Gamblin SJ, McCauley JW, Daniels RS, Howell M, Bauer D, Nastouli E, SAFER Investigators, Kassiotis G. 2021. Reduced antibody cross-reactivity following infection with B.1.1.7 than with parental 
medRxiv preprint doi: https://doi.org/10.1101/2021.08.19.21262111; this version posted August 22, 2021. The copyright holder for this preprint (which was not certified by peer review) is the author/funder, who has granted medRxiv a license to display the preprint in perpetuity. It is made available under a CC-BY-NC-ND 4.0 International license .

SARS-CoV-2 strains. Elife 10. doi:10.7554/eLife.69317

Gaebler C, Wang Z, Lorenzi JCC, Muecksch F, Finkin S, Tokuyama M, Cho A, Jankovic M, Schaefer-Babajew D, Oliveira TY, Cipolla M, Viant C, Barnes CO, Bram Y, Breton G, Hägglöf T, Mendoza P, Hurley A, Turroja M, Gordon K, Millard KG, Ramos V, Schmidt F, Weisblum Y, Jha D, Tankelevich M, Martinez-Delgado G, Yee J, Patel R, Dizon J, UnsonO'Brien C, Shimeliovich I, Robbiani DF, Zhao Z, Gazumyan A, Schwartz RE, Hatziioannou T, Bjorkman PJ, Mehandru S, Bieniasz PD, Caskey M, Nussenzweig MC. 2021. Evolution of antibody immunity to SARS-CoV-2. Nat 20215917851 591:639-644.

doi:10.1038/s41586-021-03207-w

Gudbjartsson DF, Norddahl GL, Melsted P, Gunnarsdottir K, Holm H, Eythorsson E, Arnthorsson AO, Helgason D, Bjarnadottir K, Ingvarsson RF, Thorsteinsdottir B, Kristjansdottir S, Birgisdottir K, Kristinsdottir AM, Sigurdsson MI, Arnadottir GA, Ivarsdottir E V., Andresdottir M, Jonsson F, Agustsdottir AB, Berglund J, Eiriksdottir B, Fridriksdottir R, Gardarsdottir EE, Gottfredsson M, Gretarsdottir OS, Gudmundsdottir S, Gudmundsson KR, Gunnarsdottir TR, Gylfason A, Helgason A, Jensson BO, Jonasdottir A, Jonsson $H$, Kristjansson T, Kristinsson KG, Magnusdottir DN, Magnusson OT, Olafsdottir LB, Rognvaldsson S, Roux L le, Sigmundsdottir G, Sigurdsson A, Sveinbjornsson G, Sveinsdottir KE, Sveinsdottir M, Thorarensen EA, Thorbjornsson B, Thordardottir M, Saemundsdottir J, Kristjansson SH, Josefsdottir KS, Masson G, Georgsson G, Kristjansson M, Moller A, Palsson R, Gudnason T, Thorsteinsdottir U, Jonsdottir I, Sulem P, Stefansson K. 2020. Humoral Immune Response to SARS-CoV-2 in Iceland. https://doi.org/101056/NEJMoa2026116 383:1724-1734.

doi:10.1056/NEJMOA2026116

Hall VJ, Foulkes Sarah, Charlett Andre, Atti Ana, Monk EJM, Simmons Ruth, Wellington Edgar, Cole MJ, Saei Ayoub, Oguti Blanche, Munro Katie, Wallace Sarah, Kirwan PD, Shrotri Madhumita, Vusirikala Amoolya, Rokadiya Sakib, Kall Meaghan, Zambon Maria, Ramsay Mary, Brooks Tim, Brown CS, Chand MA, Hopkins Susan, Andrews N, Atti A, Aziz H, Brooks T, Brown C, Camero D, Carr C, Chand M, Charlett A, Crawford H, Cole M, Conneely J, D’Arcangelo S, Ellis J, Evans S, Foulkes S, Gillson N, Gopal R, Hall L, Hall V, Harrington P, Hopkins S, Hewson J, Hoschler K, Ironmonger D, Islam J, Kall M, Karagiannis I, Kay O, Khawam J, King E, Kirwan P, Kyffin R, Lackenby A, Lattimore M, Linley E, Lopez-Bernal J, Mabey L, McGregor R, Miah S, Monk E, Munro K, Naheed Z, Nissr A, O'Connell A, Oguti B, Okafor H, Organ S, Osbourne J, Otter A, Patel M, Platt S, Pople D, Potts K, Ramsay M, Robotham J, Rokadiya S, Rowe C, Saei A, Sebbage G, Semper A, Shrotri M, Simmons R, Soriano A, Staves P, Taylor S, Taylor A, Tengbe A, Tonge $S$, Vusirikala A, Wallace $S$, Wellington $E$, Zambon $M$, Corrigan $D$, Sartaj $M$, Cromey L, Campbell S, Braithwaite K, Price L, Haahr L, Stewart S, Lacey E, Partridge L, Stevens $G$, Ellis $Y$, Hodgson $H$, Norman C, Larru B, Mcwilliam S, Winchester S, Cieciwa $P$, Pai A, Loughrey C, Watt A, Adair F, Hawkins A, Grant A, Temple-Purcell R, Howard J, Slawson N, Subudhi C, Davies S, Bexley A, Penn R, Wong N, Boyd G, Rajgopal A, ArenasPinto A, Matthews R, Whileman A, Laugharne R, Ledger J, Barnes T, Jones C, Botes D, Chitalia N, Akhtar S, Harrison G, Horne S, Walker N, Agwuh K, Maxwell V, Graves J, Williams S, O'Kelly A, Ridley P, Cowley A, Johnstone H, Swift P, Democratis J, Meda M, Callens C, Beazer S, Hams S, Irvine V, Chandrasekaran B, Forsyth C, Radmore J, Thomas C, Brown K, Roberts S, Burns P, Gajee K, Byrne T, Sanderson F, Knight S, Macnaughton E, Burton B, Smith H, Chaudhuri R, Hollinshead K, Shorten R, Swan A, Shorten R, 
medRxiv preprint doi: https://doi.org/10.1101/2021.08.19.21262111; this version posted August 22, 2021. The copyright holder for this preprint (which was not certified by peer review) is the author/funder, who has granted medRxiv a license to display the preprint in perpetuity. It is made available under a CC-BY-NC-ND 4.0 International license .

Favager C, Murira J, Baillon S, Hamer S, Gantert K, Russell J, Brennan D, Dave A, Chawla A, Westell F, Adeboyeku D, Papineni P, Pegg C, Williams M, Ahmad S, Ingram S, Gabriel C, Pagget K, Cieciwa P, Maloney G, Ashcroft J, Rosario I Del, Crosby-Nwaobi R, Reeks C, Fowler S, Prentice L, Spears M, McKerron G, McLelland-Brooks K, Anderson J, Donaldson S, Templeton K, Coke L, Elumogo N, Elliott J, Padgett D, Mirfenderesky M, Cross A, Price J, Joyce S, Sinanovic I, Howard M, Lewis T, Cowling P, Potoczna D, Brand S, Sheridan L, Wadams B, Lloyd A, Mouland J, Giles J, Pottinger G, Coles H, Joseph M, Lee $\mathrm{M}$, Orr S, Chenoweth $\mathrm{H}$, Auckland $\mathrm{C}$, Lear R, Mahungu T, Rodger A, Penny-Thomas K, Pai S, Zamikula J, Smith E, Stone S, Boldock E, Howcroft D, Thompson C, Aga M, Domingos P, Gormley S, Kerrison C, Marsh L, Tazzyman S, Allsop L, Ambalkar S, Beekes M, Jose S, Tomlinson J, Jones A, Price C, Pepperell J, Schultz M, Day J, Boulos A, Defever E, McCracken D, Brown K, Gray K, Houston A, Planche T, Jones RP, Wycherley D, Bennett S, Marrs J, Nimako K, Stewart B, Kalakonda N, Khanduri S, Ashby A, Holden M, Mahabir N, Harwood J, Payne B, Court K, Staines N, Longfellow R, Green M, Hughes L, Halkes $M$, Mercer P, Roebuck A, Wilson-Davies E, Gallego L, Lazarus R, Aldridge N, Berry L, Game F, Reynolds T, Holmes C, Wiselka M, Higham A, Booth M, Duff C, Alderton J, Jory H, Virgilio E, Chin T, Qazzafi M, Moody A, Tilley R, Donaghy T, Shipman K, Sierra R, Jones N, Mills G, Harvey D, Huang Y, Birch J, Robinson L, Board S, Broadley A, Laven C, Todd N, Eyre D, Jeffery K, Dunachie S, Duncan C, Klenerman P, Turtle L, Silva T De, Baxendale $\mathrm{H}$, Heeney J. 2021. SARS-CoV-2 infection rates of antibody-positive compared with antibody-negative health-care workers in England: a large, multicentre, prospective cohort study (SIREN). Lancet 397:1459-1469. doi:10.1016/S0140$6736(21) 00675-9$

Halliley JL, Tipton CM, Liesveld J, Rosenberg AF, Darce J, Gregoretti I V, Popova L, Kaminiski D, Fucile CF, Albizua I, Kyu S, Chiang KY, Bradley KT, Burack R, Slifka M, Hammarlund E, Wu H, Zhao L, Walsh EE, Falsey AR, Randall TD, Cheung WC, Sanz I, Lee FEH. 2015. Long-Lived Plasma Cells Are Contained within the CD19-CD38hiCD138+ Subset in Human Bone Marrow. Immunity 43:132-145. doi:10.1016/j.immuni.2015.06.016

Hamood R, Hamood H, Merhasin I, Keinan-Boker L. 2016. A feasibility study to assess the validity of administrative data sources and self-reported information of breast cancer survivors. Isr J Health Policy Res 5:50. doi:10.1186/s13584-016-0111-6

Ibarrondo FJ, Fulcher JA, Goodman-Meza D, Elliott J, Hofmann C, Hausner MA, Ferbas KG, Tobin NH, Aldrovandi GM, Yang OO. 2020. Rapid Decay of Anti-SARS-CoV-2 Antibodies in Persons with Mild Covid-19. https://doi.org/101056/NEJMc2025179 383:1085-1087. doi:10.1056/NEJMC2025179

Israel A, Merzon E, Schäffer AA, Shenhar Y, Green I, Golan-Cohen A, Ruppin E, Magen E, Vinker S. 2021. Elapsed time since BNT162b2 vaccine and risk of SARS-CoV-2 infection in a large cohort. medRxiv 2021.08.03.21261496. doi:10.1101/2021.08.03.21261496

Iwasaki A. 2016. Exploiting Mucosal Immunity for Antiviral Vaccines. Annu Rev Immunol 34:575-608. doi:10.1146/annurev-immunol-032414-112315

Iyer AS, Jones FK, Nodoushani A, Kelly M, Becker M, Slater D, Mills R, Teng E, Kamruzzaman M, Garcia-Beltran WF, Astudillo M, Yang D, Miller TE, Oliver E, Fischinger S, Atyeo C, lafrate AJ, Calderwood SB, Lauer SA, Yu J, Li Z, Feldman J, Hauser BM, Caradonna TM, Branda JA, Turbett SE, LaRocque RC, Mellon G, Barouch DH, Schmidt AG, Azman AS, 
medRxiv preprint doi: https://doi.org/10.1101/2021.08.19.21262111; this version posted August 22, 2021. The copyright holder for this preprint (which was not certified by peer review) is the author/funder, who has granted medRxiv a license to display the preprint in perpetuity. It is made available under a CC-BY-NC-ND 4.0 International license .

Alter G, Ryan ET, Harris JB, Charles RC. 2020. Persistence and decay of human antibody responses to the receptor binding domain of SARS-CoV-2 spike protein in COVID-19 patients. Sci Immunol 5:367. doi:10.1126/SCIIMMUNOL.ABE0367

Khoury DS, Cromer D, Reynaldi A, Schlub TE, Wheatley AK, Juno JA, Subbarao K, Kent SJ, Triccas JA, Davenport MP. 2021. Neutralizing antibody levels are highly predictive of immune protection from symptomatic SARS-CoV-2 infection. Nat Med 2021277 27:1205-1211. doi:10.1038/s41591-021-01377-8

Kim JH, Marks F, Clemens JD. 2021. Looking beyond COVID-19 vaccine phase 3 trials. Nat Med 2021272 27:205-211. doi:10.1038/s41591-021-01230-y

L'Huillier AG, Meyer B, Andrey DO, Arm-Vernez I, Baggio S, Didierlaurent A, Eberhardt CS, Eckerle I, Grasset-Salomon C, Huttner A, Posfay-Barbe KM, Royo IS, Pralong JA, Vuilleumier N, Yerly S, Siegrist CA, Kaiser L. 2021. Antibody persistence in the first 6 months following SARS-CoV-2 infection among hospital workers: a prospective longitudinal study. Clin Microbiol Infect 27:784.e1-784.e8. doi:10.1016/j.cmi.2021.01.005

Li C, Yu D, Wu X, Liang H, Zhou Z, Xie Y, Li T, Wu J, Lu F, Feng L, Mao M, Lin L, Guo H, Yue S, Wang F, Peng Y, Hu Y, Wang Z, Yu J, Zhang Yong, Lu J, Ning H, Yang H, Fu D, He Y, Zhou D, Du T, Duan K, Dong D, Deng K, Zou X, Zhang Ya, Zhou R, Gao Y, Zhang X, Yang X. 2021. Twelve-month specific IgG response to SARS-CoV-2 receptor-binding domain among COVID-19 convalescent plasma donors in Wuhan. Nat Commun 2021 121 12:19. doi:10.1038/s41467-021-24230-5

Li D, Edwards RJ, Manne K, Martinez DR, Schäfer A, Alam SM, Wiehe K, Lu X, Parks R, Sutherland LL, Oguin TH, McDanal C, Perez LG, Mansouri K, Gobeil SMC, Janowska K, Stalls V, Kopp M, Cai F, Lee E, Foulger A, Hernandez GE, Sanzone A, Tilahun K, Jiang C, Tse L V., Bock KW, Minai M, Nagata BM, Cronin K, Gee-Lai V, Deyton M, Barr M, Von Holle T, Macintyre AN, Stover E, Feldman J, Hauser BM, Caradonna TM, Scobey TD, Rountree W, Wang Y, Moody MA, Cain DW, DeMarco CT, Denny TN, Woods CW, Petzold EW, Schmidt AG, Teng IT, Zhou T, Kwong PD, Mascola JR, Graham BS, Moore IN, Seder R, Andersen H, Lewis MG, Montefiori DC, Sempowski GD, Baric RS, Acharya P, Haynes BF, Saunders KO. 2021. In vitro and in vivo functions of SARS-CoV-2 infectionenhancing and neutralizing antibodies. Cell 184:4203-4219.e32.

doi:10.1016/J.CELL.2021.06.021

Lumley S. 2021. Antibody status and incidence of SARS-CoV-2 infection in health care workers. N Engl J Med 384:533-540. doi:10.1056/nejmoa2034545

Martínez-Flores D, Zepeda-Cervantes J, Cruz-Reséndiz A, Aguirre-Sampieri S, Sampieri A, Vaca L. 2021. SARS-CoV-2 Vaccines Based on the Spike Glycoprotein and Implications of New Viral Variants. Front Immunol 12:701501. doi:10.3389/fimmu.2021.701501

McMahan K, Yu J, Mercado NB, Loos C, Tostanoski LH, Chandrashekar A, Liu J, Peter L, Atyeo C, Zhu A, Bondzie EA, Dagotto G, Gebre MS, Jacob-Dolan C, Li Z, Nampanya F, Patel S, Pessaint L, Van Ry A, Blade K, Yalley-Ogunro J, Cabus M, Brown R, Cook A, Teow E, Andersen H, Lewis MG, Lauffenburger DA, Alter G, Barouch DH. 2020. Correlates of protection against SARS-CoV-2 in rhesus macaques. Nat 2020 5907847 590:630-634. doi:10.1038/s41586-020-03041-6 
medRxiv preprint doi: https://doi.org/10.1101/2021.08.19.21262111; this version posted August 22, 2021. The copyright holder for this preprint (which was not certified by peer review) is the author/funder, who has granted medRxiv a license to display the preprint in perpetuity. It is made available under a CC-BY-NC-ND 4.0 International license .

Muhsen K, Na'aminh W, Lapidot Y, Goren S, Amir Y, Perlman S, Green MS, Chodick G, Cohen D. 2021. A nationwide analysis of population group differences in the COVID-19 epidemic in Israel, February 2020-February 2021. Lancet Reg Heal - Eur 7:100130. doi:10.1016/j.lanepe.2021.100130

Nutt SL, Hodgkin PD, Tarlinton DM, Corcoran LM. 2015. The generation of antibodysecreting plasma cells. Nat Rev Immunol 15:160-171. doi:10.1038/nri3795

Padoan A, Dall'Olmo L, Rocca F Della, Barbaro F, Cosma C, Basso D, Cattelan A, Cianci V, Plebani M. 2021. Antibody response to first and second dose of BNT162b2 in a cohort of characterized healthcare workers. Clin Chim Acta 519:60-63. doi:10.1016/j.cca.2021.04.006

Perkmann T, Perkmann-Nagele N, Breyer M-K, Breyer-Kohansal R, Burghuber OC, Hartl S, Aletaha D, Sieghart D, Quehenberger P, Marculescu R, Mucher P, StrassI R, Wagner OF, Binder CJ, Haslacher H. 2020. Side by side comparison of three fully automated SARSCoV-2 antibody assays with a focus on specificity. Clin Chem 66:1405-1413. doi:10.1093/CLINCHEM/HVAA198

Raz A, Keshet Y, Popper-Giveon A, Karkabi MS. 2021. One size does not fit all: Lessons from Israel's Covid-19 vaccination drive and hesitancy. Vaccine 39:4027-4028. doi:10.1016/j.vaccine.2021.06.004

Rennert G, Peterburg Y. 2001. Prevalence of selected chronic diseases in Israel. Isr Med Assoc J 3:404-8.

Sahin U, Muik A, Derhovanessian E, Vogler I, Kranz LM, Vormehr M, Baum A, Pascal K, Quandt J, Maurus D, Brachtendorf S, Lörks V, Sikorski J, Hilker R, Becker D, Eller A-K, Grützner J, Boesler C, Rosenbaum C, Kühnle M-C, Luxemburger U, Kemmer-Brück $A$, Langer D, Bexon M, Bolte S, Karikó K, Palanche T, Fischer B, Schultz A, Shi P-Y, FontesGarfias C, Perez JL, Swanson KA, Loschko J, Scully IL, Cutler M, Kalina W, Kyratsous CA, Cooper D, Dormitzer PR, Jansen KU, Türeci Ö. 2020. COVID-19 vaccine BNT162b1 elicits human antibody and TH1 T cell responses. Nat 20205867830 586:594-599. doi:10.1038/s41586-020-2814-7

Salvagno GL, Henry BM, di Piazza G, Pighi L, De Nitto S, Bragantini D, Gianfilippi GL, Lippi G. 2021. Anti-SARS-CoV-2 Receptor-Binding Domain Total Antibodies Response in Seropositive and Seronegative Healthcare Workers Undergoing COVID-19 mRNA BNT162b2 Vaccination. Diagnostics (Basel, Switzerland) 11.

doi:10.3390/diagnostics11050832

Schoof M, Faust B, Saunders RA, Sangwan S, Rezelj V, Hoppe N, Boone M, Billesbølle CB, Puchades C, Azumaya CM, Kratochvil HT, Zimanyi M, Deshpande I, Liang J, Dickinson S, Nguyen HC, Chio CM, Merz GE, Thompson MC, Diwanji D, Schaefer K, Anand AA, Dobzinski N, Zha BS, Simoneau CR, Leon K, White KM, Chio US, Gupta M, Jin M, Li F, Liu Yanxin, Zhang K, Bulkley D, Sun M, Smith AM, Rizo AN, Moss F, Brilot AF, Pourmal S, Trenker R, Pospiech T, Gupta S, Barsi-Rhyne B, Belyy V, Barile-Hill AW, Nock S, Liu Yuwei, Krogan NJ, Ralston CY, Swaney DL, García-Sastre A, Ott M, Vignuzzi M, Consortium4‡ QSB, Walter P, Manglik A. 2020. An ultrapotent synthetic nanobody neutralizes SARS-CoV-2 by stabilizing inactive Spike. Science (80- ) 370:1473-1479. doi:10.1126/SCIENCE.ABE3255 
medRxiv preprint doi: https://doi.org/10.1101/2021.08.19.21262111; this version posted August 22, 2021. The copyright holder for this preprint (which was not certified by peer review) is the author/funder, who has granted medRxiv a license to display the preprint in perpetuity. It is made available under a CC-BY-NC-ND 4.0 International license .

Seow J, Graham C, Merrick B, Acors S, Pickering S, Steel KJA, Hemmings O, O'Byrne A, Kouphou N, Galao RP, Betancor G, Wilson HD, Signell AW, Winstone H, Kerridge C, Huettner I, Jimenez-Guardeño JM, Lista MJ, Temperton N, Snell LB, Bisnauthsing K, Moore A, Green A, Martinez L, Stokes B, Honey J, Izquierdo-Barras A, Arbane G, Patel A, Tan MKI, O'Connell L, O’Hara G, MacMahon E, Douthwaite S, Nebbia G, Batra R, Martinez-Nunez R, Shankar-Hari M, Edgeworth JD, Neil SJD, Malim MH, Doores KJ. 2020. Longitudinal observation and decline of neutralizing antibody responses in the three months following SARS-CoV-2 infection in humans. Nat Microbiol 2020512 5:1598-1607. doi:10.1038/s41564-020-00813-8

Tong P, Gautam A, Windsor IW, Travers M, Chen Y, Garcia N, Whiteman NB, McKay LGA, Storm N, Malsick LE, Honko AN, Lelis FJN, Habibi S, Jenni S, Cai Y, Rennick L, Duprex WP, McCarthy KR, Lavine CL, Zuo T, Lin J, Zuiani A, Feldman J, MacDonald EA, Hauser BM, Griffths A, Seaman MS, Schmidt AG, Chen B, Neuberg D, Bajic G, Harrison SC, Wesemann DR. 2021. Memory B cell repertoire for recognition of evolving SARS-CoV-2 spike. Cell. doi:10.1016/j.cell.2021.07.025

Tré-Hardy M, Cupaiolo R, Papleux E, Wilmet A, Horeanga A, Antoine-Moussiaux T, Della Vecchia A, Beukinga I, Vekemans M, Blairon L. 2021. Reactogenicity, safety and antibody response, after one and two doses of mRNA-1273 in seronegative and seropositive healthcare workers. J Infect 83:237-279. doi:10.1016/j.jinf.2021.03.025

Turner JS, Kim W, Kalaidina E, Goss CW, Rauseo AM, Schmitz AJ, Hansen L, Haile A, Klebert MK, Pusic I, O'Halloran JA, Presti RM, Ellebedy AH. 2021a. SARS-CoV-2 infection induces long-lived bone marrow plasma cells in humans. Nature 595:421-425. doi:10.1038/s41586-021-03647-4

Turner JS, O'Halloran JA, Kalaidina E, Kim W, Schmitz AJ, Zhou JQ, Lei T, Thapa M, Chen RE, Case JB, Amanat F, Rauseo AM, Haile A, Xie X, Klebert MK, Suessen T, Middleton WD, Shi P-Y, Krammer F, Teefey SA, Diamond MS, Presti RM, Ellebedy AH. 2021b. SARS-CoV2 mRNA vaccines induce persistent human germinal centre responses. Nature 596:109113. doi:10.1038/s41586-021-03738-2

Wang P, Nair MS, Liu L, Iketani S, Luo Y, Guo Y, Wang M, Yu J, Zhang B, Kwong PD, Graham BS, Mascola JR, Chang JY, Yin MT, Sobieszczyk M, Kyratsous CA, Shapiro L, Sheng Z, Huang Y, Ho DD. 2021. Antibody resistance of SARS-CoV-2 variants B.1.351 and B.1.1.7. Nat 2021 5937857 593:130-135. doi:10.1038/s41586-021-03398-2

Wheatley AK, Juno JA, Wang JJ, Selva KJ, Reynaldi A, Tan H-X, Lee WS, Wragg KM, Kelly HG, Esterbauer R, Davis SK, Kent HE, Mordant FL, Schlub TE, Gordon DL, Khoury DS, Subbarao K, Cromer D, Gordon TP, Chung AW, Davenport MP, Kent SJ. 2021. Evolution of immune responses to SARS-CoV-2 in mild-moderate COVID-19. Nat Commun 2021 121 12:1-11. doi:10.1038/s41467-021-21444-5

Xu J, Xu K, Jung S, Conte A, Lieberman J, Muecksch F, Lorenzi JCC, Park S, Schmidt F, Wang Z, Huang Y, Luo Y, Nair MS, Wang P, Schulz JE, Tessarollo L, Bylund T, Chuang G-Y, Olia AS, Stephens T, Teng I-T, Tsybovsky Y, Zhou T, Munster V, Ho DD, Hatziioannou T, Bieniasz PD, Nussenzweig MC, Kwong PD, Casellas R. 2021. Nanobodies from camelid mice and Ilamas neutralize SARS-CoV-2 variants. Nat 20215957866 595:278-282.

doi:10.1038/s41586-021-03676-z 
medRxiv preprint doi: https://doi.org/10.1101/2021.08.19.21262111; this version posted August 22, 2021. The copyright holder for this preprint (which was not certified by peer review) is the author/funder, who has granted medRxiv a license to display the preprint in perpetuity. It is made available under a CC-BY-NC-ND 4.0 International license.

Zabelin NN, Gribauskas PS, Moisseenok AG. n.d. [Ultrasonic coagulometry as a method of testing compounds with antiplasmin activity]. Biofizika 33:226-8.

\section{Acknowledgements:}

The content of this publication does not necessarily reflect the views or policies of the Department of Health and Human Services, nor does mention of trade names, commercial products, or organizations imply endorsement by the US Government. 
medRxiv preprint doi: https://doi.org/10.1101/2021.08.19.21262111; this version posted August 22, 2021. The copyright holder for this preprint (which was not certified by peer review) is the author/funder, who has granted medRxiv a license to display the preprint in perpetuity.

It is made available under a CC-BY-NC-ND 4.0 International license .

Table 1. The demographic characteristics of tested individuals in the vaccinated and convalescent population

\begin{tabular}{|c|c|c|c|}
\hline & & Vaccinated & Convalescent \\
\hline $\mathbf{N}$ & & 2,653 & 4,361 \\
\hline Age (in years) & mean (SD) & $56.45(15.87)$ & 41.99 (16.09) \\
\hline \multirow{2}{*}{$\begin{array}{l}\text { Age group } \\
\mathrm{n}(\%)\end{array}$} & $18-59$ years & $1,296(48.9 \%)$ & $3,663(84.0 \%)$ \\
\hline & $\geq 60$ years & $1,357(51.1 \%)$ & $698(16.0 \%)$ \\
\hline \multirow{2}{*}{ Sex, $n(\%)$} & Female & $1,604(60.5 \%)$ & $2,728(62.6 \%)$ \\
\hline & Male & 1,049 (39.5 \%) & $1,633(37.4 \%)$ \\
\hline \multirow{3}{*}{$\begin{array}{l}\text { Ethnic group, } n \\
\text { (\%) }\end{array}$} & Arab & $248(10.9 \%)$ & $615(14.1 \%)$ \\
\hline & $\begin{array}{c}\text { General (mostly } \\
\text { Jewish) }\end{array}$ & $1,633(71.9 \%)$ & $1,959(44.9 \%)$ \\
\hline & Jewish Ultra-orthodox & $389(17.1 \%)$ & $1,787(41.0 \%)$ \\
\hline \multirow{2}{*}{ SES, mean (SD) } & & $9.88(3.70)$ & $7.57(3.55)$ \\
\hline & ${ }^{*}$ missing* & $179(7.24 \%)$ & $253(6.16 \%)$ \\
\hline \multirow{2}{*}{$\begin{array}{l}\text { Body mass index } \\
\text { (BMI) }\end{array}$} & mean (SD) & $27.79(5.26)$ & $27.20(5.74)$ \\
\hline & ${ }^{*}$ missing* & $35(1.34 \%)$ & $92(2.16 \%)$ \\
\hline \multirow{7}{*}{$\begin{array}{l}\text { BMI category, } \\
\text { n (\%) }\end{array}$} & $<18.5$ Underweight & $46(1.8 \%)$ & $135(3.2 \%)$ \\
\hline & 18.5-25 Normal & $780(29.8 \%)$ & $1,468(34.4 \%)$ \\
\hline & 25 - 30 Overweight & $994(38.0 \%)$ & $1,470(34.5 \%)$ \\
\hline & $30-35$ Obese I & $550(21.0 \%)$ & $781(18.3 \%)$ \\
\hline & 35 - 40 Obese II & $195(7.5 \%)$ & $304(7.1 \%)$ \\
\hline & 40 - Obese III & $51(1.9 \%)$ & $105(2.5 \%)$ \\
\hline & ${ }^{*}$ missing* & $37(1.4 \%)$ & $98(2.2 \%)$ \\
\hline \multirow{7}{*}{$\begin{array}{l}\text { co-morbidities, } \\
\text { n (\%) }\end{array}$} & diabetes mellitus & $659(24.8 \%)$ & $493(11.3 \%)$ \\
\hline & hypertension & $1,140(43.0 \%)$ & $808(18.5 \%)$ \\
\hline & asthma & $299(11.3 \%)$ & 409 (9.4\%) \\
\hline & COPD & $265(10.0 \%)$ & $137(3.1 \%)$ \\
\hline & ischemic heart disease & $325(12.3 \%)$ & $183(4.2 \%)$ \\
\hline & solid tumor & $342(12.9 \%)$ & $172(3.9 \%)$ \\
\hline & chronic renal disease & $199(7.5 \%)$ & $58(1.3 \%)$ \\
\hline \multirow{2}{*}{$\begin{array}{l}\text { Time (in days) } \\
\text { since... mean (SD) }\end{array}$} & $2^{\text {nd }}$ vaccination & $101.35(65.73)$ & - \\
\hline & first positive PCR & - & $151.17(82.32)$ \\
\hline \multirow{10}{*}{$\begin{array}{l}\text { Time (in days) } \\
\text { since vaccination } \\
\text { or positive PCR } \\
\text { by } 30 \text { days } \\
\text { intervals, } \\
\mathrm{n}(\%)\end{array}$} & $0-29$ & $556(21.0 \%)$ & $269(6.2 \%)$ \\
\hline & $30-59$ & $456(17.2 \%)$ & $499(11.4 \%)$ \\
\hline & $60-89$ & $289(10.9 \%)$ & $341(7.8 \%)$ \\
\hline & $90-119$ & $200(7.5 \%)$ & $331(7.6 \%)$ \\
\hline & $120-149$ & $170(6.4 \%)$ & $700(16.1 \%)$ \\
\hline & $150-179$ & $542(20.4 \%)$ & $735(16.9 \%)$ \\
\hline & $180-209$ & $440(16.6 \%)$ & $587(13.5 \%)$ \\
\hline & $210-239$ & - & $365(8.4 \%)$ \\
\hline & $240-269$ & - & $161(3.7 \%)$ \\
\hline & $270-$ & - & $373(8.6 \%)$ \\
\hline
\end{tabular}

SES: socio-economic status; BMI: body mass index; COPD: chronic obstructive pulmonary disease 
Table 2a. Serology results of vaccinated individuals by 30 days intervals since second vaccination

\begin{tabular}{|c|c|c|c|c|c|c|c|c|}
\hline \multicolumn{2}{|c|}{$\begin{array}{l}\text { Time since second vaccine } \\
\text { injection (in days) }\end{array}$} & $0-29$ & $30-59$ & $60-89$ & $90-119$ & $120-149$ & $150-179$ & $180-$ \\
\hline $\mathbf{N}$ & & 556 & 456 & 289 & 200 & 170 & 542 & 440 \\
\hline Age (in years) & & $53.76(16.90)$ & $55.41(16.66)$ & $55.64(16.52)$ & $53.31(16.75)$ & $53.29(16.29)$ & $56.34(13.76)$ & $64.23(12.30)$ \\
\hline \multirow{2}{*}{ Sex, n (\%) } & Female & 318 (57.2 \%) & 273 (59.9 \%) & 173 (59.9 \%) & 129 (64.5 \%) & 104 (61.2 \%) & 358 (66.1\%) & 249 (56.6\%) \\
\hline & Male & $238(42.8 \%)$ & 183 (40.1\%) & 116 (40.1 \%) & 71 (35.5\%) & 66 (38.8 \%) & 184 (33.9 \%) & 191 (43.4 \%) \\
\hline \multirow{4}{*}{$\begin{array}{c}\text { SARS-CoV-2 } \\
\text { IgG antibody } \\
\text { level }\end{array}$} & mean & 12153 & 6848 & 3476 & 2383 & 1552 & 1122 & 765 \\
\hline & (SD) & (9875) & $(6340)$ & (4582) & (3266) & $(2103)$ & (1431) & (948) \\
\hline & median & 9913 & 5106 & 2159 & 1323 & 1071 & 764 & 447 \\
\hline & [IQR] & [3650-18733] & [2109-9601] & [1039-4169] & [549-3126] & [471-1901] & [385-1343] & [205-966] \\
\hline
\end{tabular}

Table $\mathbf{2 b}$. Serology results of convalescent patients by 30 days intervals since second first positive PCR test

\begin{tabular}{|c|c|c|c|c|c|c|c|c|c|c|c|}
\hline \multicolumn{2}{|c|}{$\begin{array}{l}\text { Time since first positive PCR } \\
\text { (in days) }\end{array}$} & $0-29$ & $30-59$ & $60-89$ & $90-119$ & $120-149$ & $150-179$ & $180-209$ & 210-239 & $240-269$ & $270-$ \\
\hline $\mathbf{N}$ & & 269 & 499 & 341 & 331 & 700 & 735 & 587 & 365 & 161 & 373 \\
\hline Age (in years) & & $\begin{array}{c}39.96 \\
(14.78)\end{array}$ & $\begin{array}{c}41.10 \\
(14.95)\end{array}$ & $\begin{array}{c}45.07 \\
(16.53)\end{array}$ & $\begin{array}{c}43.52 \\
(16.32)\end{array}$ & $\begin{array}{c}42.90 \\
(16.23)\end{array}$ & $\begin{array}{c}40.95 \\
(16.13)\end{array}$ & $\begin{array}{c}41.39 \\
(16.14)\end{array}$ & $\begin{array}{c}40.59 \\
(15.32)\end{array}$ & $\begin{array}{c}41.75 \\
(17.42)\end{array}$ & $\begin{array}{c}43.18 \\
(17.10)\end{array}$ \\
\hline \multirow{2}{*}{ Sex, n (\%) } & Female & $\begin{array}{c}157 \\
(58.4 \%)\end{array}$ & $\begin{array}{c}326 \\
(65.3 \%)\end{array}$ & $\begin{array}{c}234 \\
(68.6 \%)\end{array}$ & $\begin{array}{c}219 \\
(66.2 \%)\end{array}$ & $\begin{array}{c}400 \\
(57.1 \%)\end{array}$ & $\begin{array}{c}461 \\
(62.7 \%)\end{array}$ & $\begin{array}{c}371 \\
(63.2 \%)\end{array}$ & $\begin{array}{c}230 \\
(63.0 \%)\end{array}$ & $\begin{array}{c}112 \\
(69.6 \%)\end{array}$ & $\begin{array}{c}218 \\
(58.4 \%)\end{array}$ \\
\hline & Male & $\begin{array}{c}112 \\
(41.6 \%)\end{array}$ & $\begin{array}{c}173 \\
(34.7 \%)\end{array}$ & $\begin{array}{c}107 \\
(31.4 \%)\end{array}$ & $\begin{array}{c}112 \\
(33.8 \%)\end{array}$ & $\begin{array}{c}300 \\
(42.9 \%)\end{array}$ & $\begin{array}{c}274 \\
(37.3 \%)\end{array}$ & $\begin{array}{c}216 \\
(36.8 \%)\end{array}$ & $\begin{array}{c}135 \\
(37.0 \%)\end{array}$ & $\begin{array}{c}49 \\
(30.4 \%)\end{array}$ & $\begin{array}{c}155 \\
(41.6 \%)\end{array}$ \\
\hline \multirow{2}{*}{$\begin{array}{c}\text { SARS-CoV-2 } \\
\text { IgG antibody } \\
\text { level }\end{array}$} & $\begin{array}{l}\text { mean } \\
(S D)\end{array}$ & $\begin{array}{c}1914 \\
(3870)\end{array}$ & $\begin{array}{c}1739 \\
(2972)\end{array}$ & $\begin{array}{c}1552 \\
(2522)\end{array}$ & $\begin{array}{c}1195 \\
(2406)\end{array}$ & $\begin{array}{c}1079 \\
(2556)\end{array}$ & $\begin{array}{c}860 \\
(1962)\end{array}$ & $\begin{array}{c}904 \\
(2384)\end{array}$ & $\begin{array}{c}850 \\
(2104)\end{array}$ & $\begin{array}{c}901 \\
(1739)\end{array}$ & $\begin{array}{c}731 \\
(1280)\end{array}$ \\
\hline & $\begin{array}{l}\text { median } \\
\text { [IQR] }\end{array}$ & $\begin{array}{c}490 \\
{[109-1869]}\end{array}$ & $\begin{array}{c}586 \\
{[212-1908]}\end{array}$ & $\begin{array}{c}538 \\
{[247-1723]}\end{array}$ & $\begin{array}{c}377 \\
{[165-1080]}\end{array}$ & $\begin{array}{c}329 \\
{[140-886]}\end{array}$ & $\begin{array}{c}312 \\
{[138-8301]}\end{array}$ & $\begin{array}{c}278 \\
{[125-751]}\end{array}$ & $\begin{array}{c}278 \\
{[105-727]}\end{array}$ & $\begin{array}{c}351 \\
{[124-919]}\end{array}$ & $\begin{array}{c}314 \\
{[116-783]}\end{array}$ \\
\hline
\end{tabular}


Table 3. Linear regression models of SARS-CoV-2 IgG antibody titer

\begin{tabular}{|c|c|c|c|c|c|c|c|}
\hline & & \multicolumn{3}{|c|}{ Vaccinated } & \multicolumn{3}{|c|}{ Convalescent } \\
\hline & & factor & $95 \% \mathrm{Cl}$ & $\mathbf{P}$ & factor & $95 \% \mathrm{Cl}$ & $\mathbf{P}$ \\
\hline \multicolumn{2}{|c|}{ (Intercept) } & 10,598 & {$[4,889-22,975]$} & $<0.001$ & 234 & [143-384] & $<0.001$ \\
\hline \multicolumn{2}{|c|}{ Each month since vaccination } & 0.623 & [0.599-0.649] & $<0.001$ & & & \\
\hline \multicolumn{2}{|c|}{$\begin{array}{c}\text { Each month since first positive } \\
\text { (for convalescent) }\end{array}$} & & & & 0.960 & [0.939-0.982] & $<0.001$ \\
\hline \multicolumn{2}{|c|}{ was symptomatic (for convalescent) } & & & & 1.811 & [1.531-2.142] & $<0.001$ \\
\hline \multicolumn{2}{|c|}{ was hospitalized (for convalescent) } & & & & 3.323 & {$[2.217-4.980]$} & $<0.001$ \\
\hline Age & $\geq 60$ (vs. $<60$ ) & 0.790 & [0.644-0.969] & 0.024 & 1.546 & {$[1.269-1.884]$} & $<0.001$ \\
\hline Sex & Female (vs. Male) & 1.243 & {$[1.035-1.492]$} & 0.020 & 0.923 & [0.812-1.048] & 0.215 \\
\hline \multicolumn{2}{|c|}{ Socio-economic status (SES) } & 0.995 & {$[0.966-1.024]$} & 0.723 & 0.995 & [0.973-1.018] & 0.662 \\
\hline \multirow{2}{*}{$\begin{array}{c}\text { Ethnicity } \\
\text { (vs. general) }\end{array}$} & Arab & 1.525 & [1.101-2.113] & 0.011 & 0.982 & [0.789-1.222] & 0.871 \\
\hline & Ultra-orthodox & 1.436 & [1.099-1.877] & 0.008 & 1.261 & [1.065-1.492] & 0.007 \\
\hline \multirow{5}{*}{$\begin{array}{l}\text { Body Mass Index } \\
\text { (BMI) }\end{array}$} & $<18.5$ Underweight & 0.359 & [0.144-0.893] & 0.028 & 0.683 & [0.404-1.157] & 0.156 \\
\hline & 18.5-25 Normal & 0.757 & [0.374-1.534] & 0.440 & 0.880 & [0.581-1.333] & 0.547 \\
\hline & 25-30 Overweight & 0.774 & [0.383-1.564] & 0.475 & 1.143 & [0.754-1.733] & 0.529 \\
\hline & 30-35 Obese & 0.804 & [0.393-1.645] & 0.550 & 1.429 & [0.930-2.194] & 0.103 \\
\hline & $\geq 35$ Obese II+ & 0.647 & [0.307-1.363] & 0.252 & 1.839 & [1.166-2.899] & 0.009 \\
\hline \multirow{7}{*}{ Co-morbidities } & diabetes mellitus & 0.720 & [0.579-0.894] & 0.003 & 1.354 & [1.093-1.678] & 0.006 \\
\hline & hypertension & 0.786 & [0.639-0.966] & 0.022 & 1.254 & [1.036-1.518] & 0.020 \\
\hline & asthma & 1.200 & [0.911-1.582] & 0.195 & 1.046 & [0.848-1.290] & 0.676 \\
\hline & COPD & 0.643 & [0.479-0.863] & 0.003 & 0.798 & [0.562-1.133] & 0.207 \\
\hline & $\begin{array}{l}\text { ischemic heart } \\
\text { disease }\end{array}$ & 0.869 & {$[0.655-1.152]$} & 0.328 & 1.322 & [0.956-1.828] & 0.091 \\
\hline & solid tumor & 0.642 & [0.494-0.834] & 0.001 & 1.048 & {$[0.760-1.444]$} & 0.777 \\
\hline & $\begin{array}{c}\text { chronic renal } \\
\text { disease }\end{array}$ & 0.200 & [0.143-0.281] & $<0.001$ & 1.965 & [1.134-3.407] & 0.016 \\
\hline
\end{tabular}

Regression coefficients were obtained by fitting a linear regression model for the log of antibody titer. They are displayed after exponentiation, they are therefore multiplicative: the expected antibody titer equals the intercept multiplied by each factor 
medRxiv preprint doi: https://doi.org/10.1101/2021.08.19.21262111; this version posted August 22, 2021. The copyright holder for this preprint (which was not certified by peer review) is the author/funder, who has granted medRxiv a license to display the preprint in perpetuity.

It is made available under a CC-BY-NC-ND 4.0 International license .

Figure 1a.

antibody titer ranges after BNT162b2 vaccination

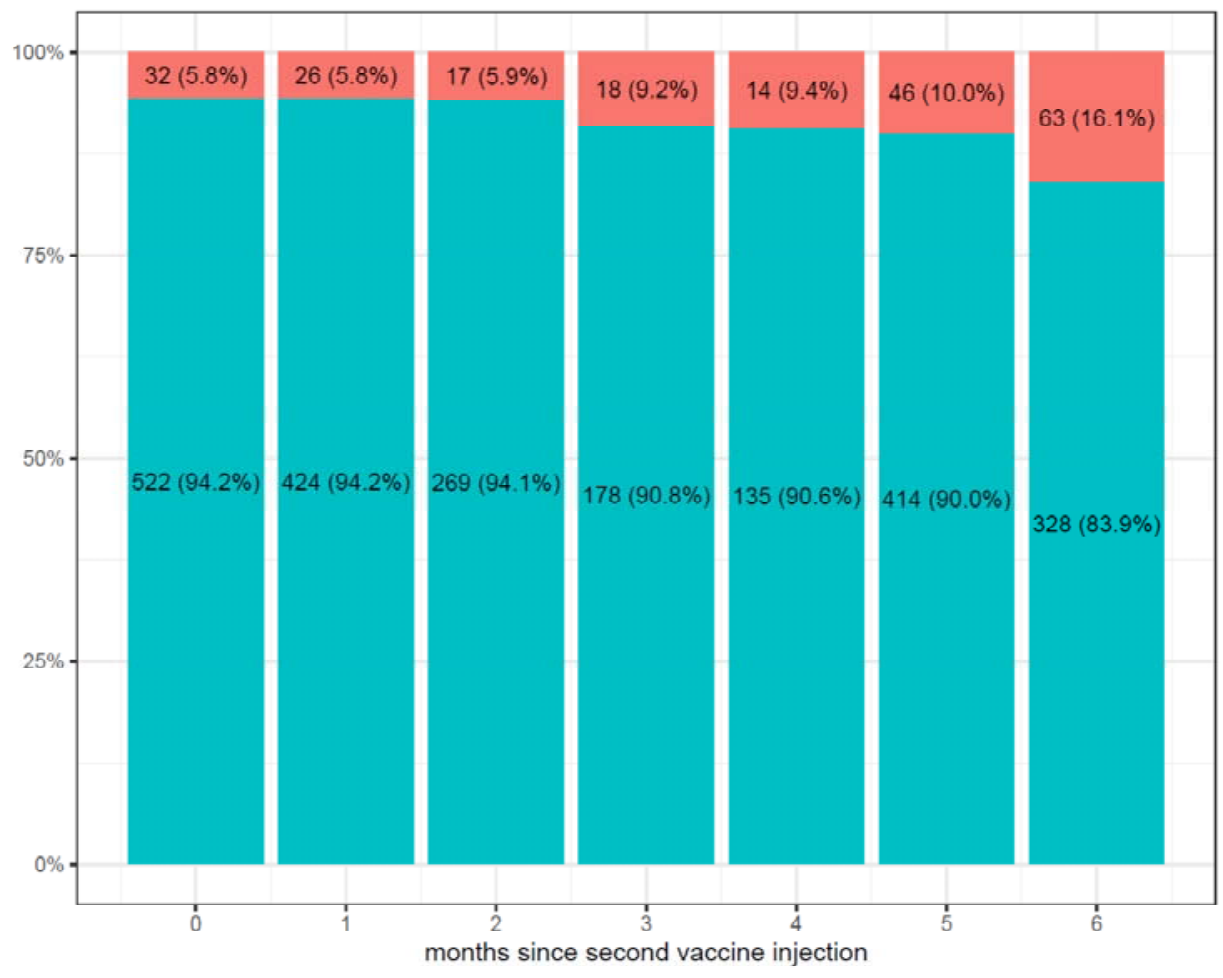

antibody titer range

$<0$
$\geq 50$

250

Figure 1b.

antibody titer ranges after SARS-CoV-2 infection

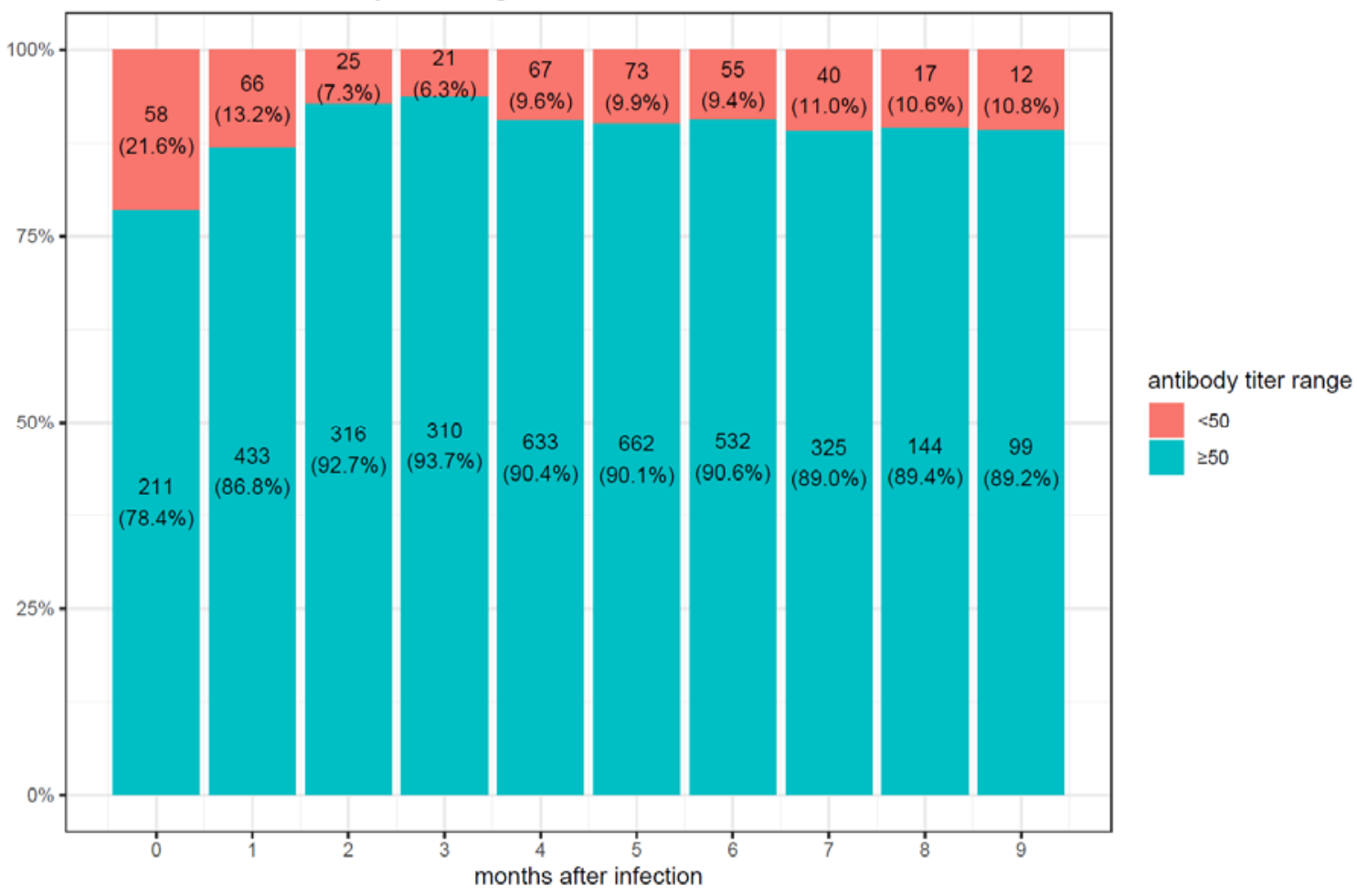


medRxiv preprint doi: https://doi.org/10.1101/2021.08.19.21262111; this version posted August 22, 2021. The copyright holder for this preprint (which was not certified by peer review) is the author/funder, who has granted medRxiv a license to display the preprint in perpetuity.

It is made available under a CC-BY-NC-ND 4.0 International license .

Figure 2a.

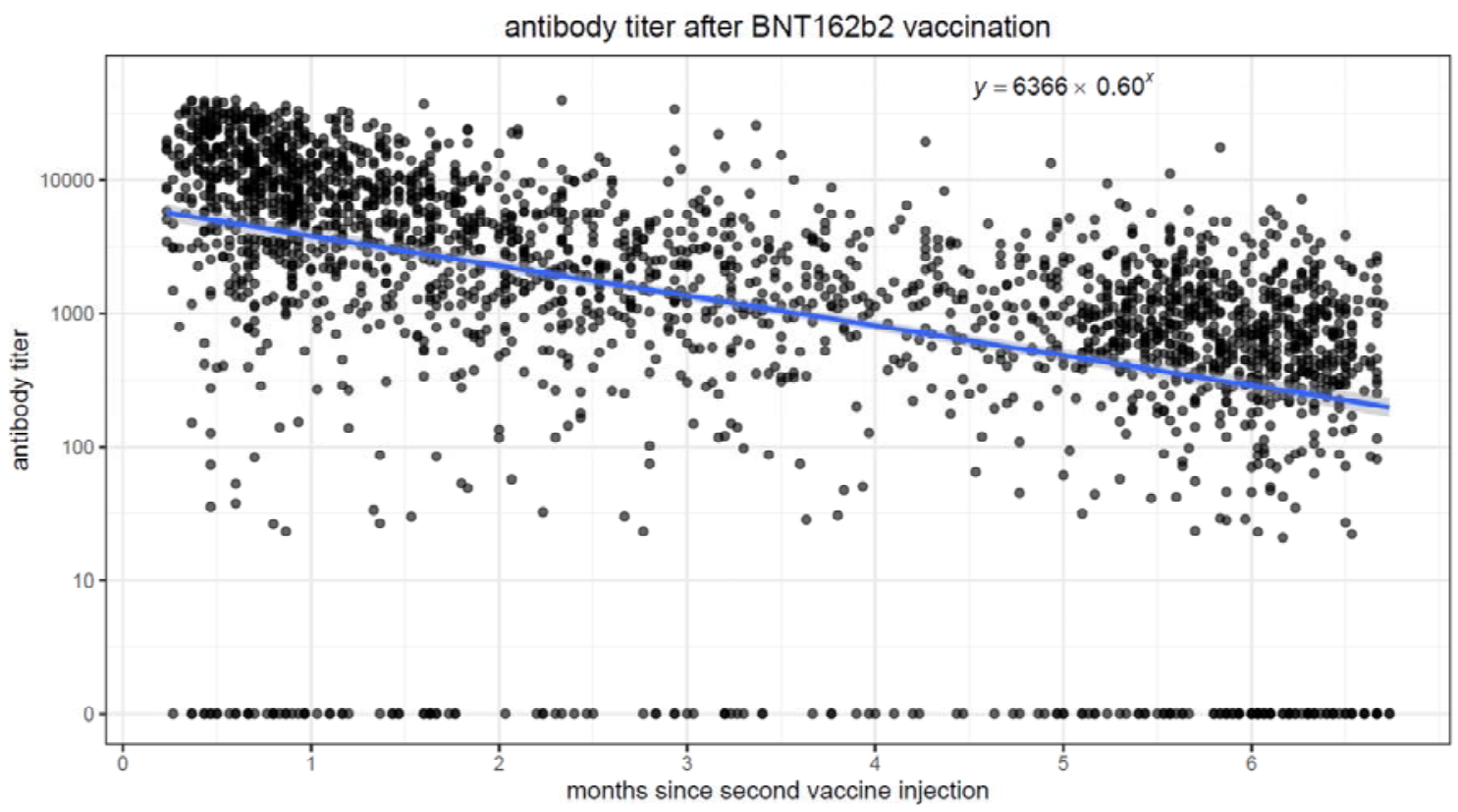

Figure 2b.

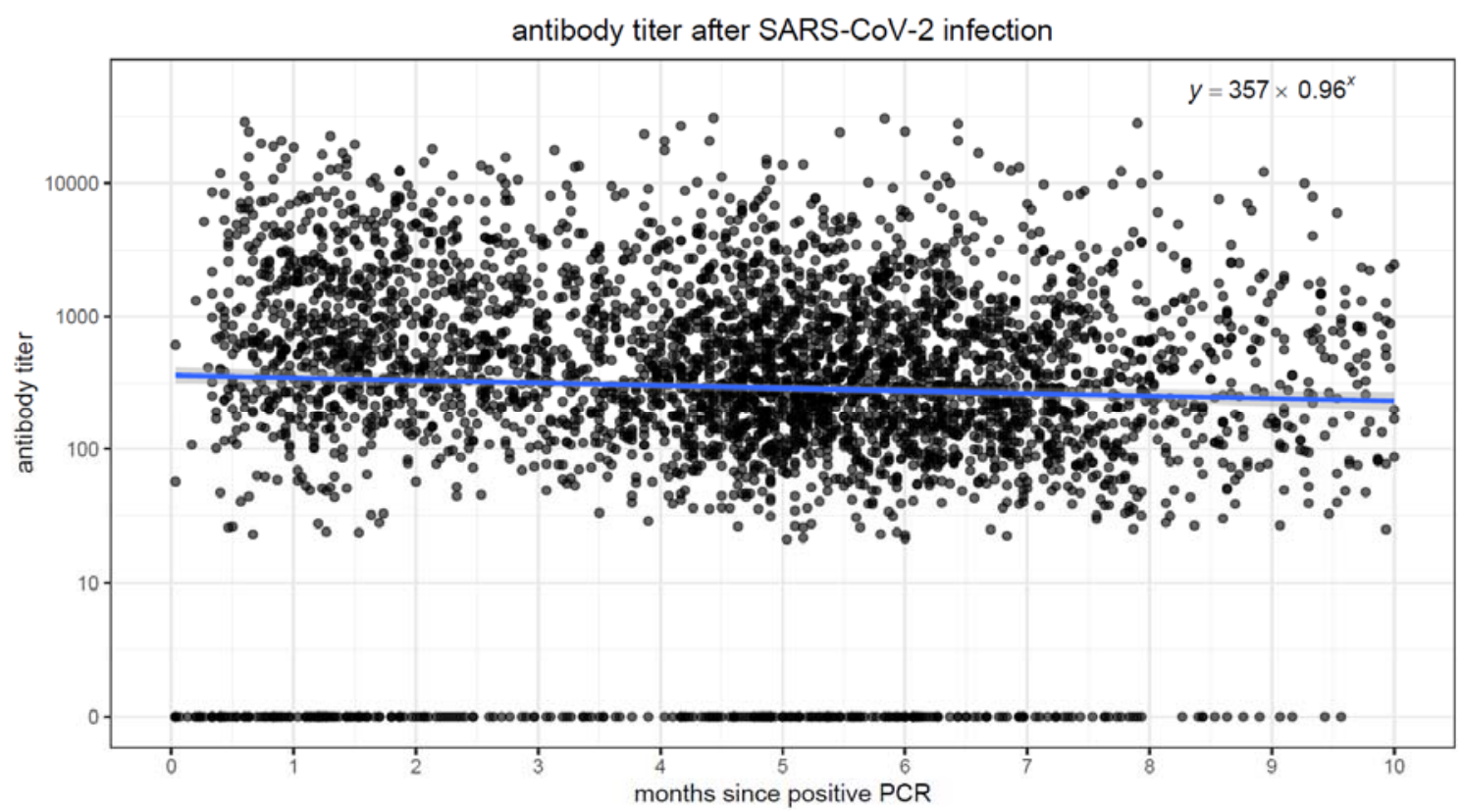

